\title{
MENGINTIP WISATA SYARIAH DI PULAU SANTEN BANYUWANGI
}

\author{
M. Amir Mahmud \\ Institut Agama Islam Ibrahimy Genteng Banyuwangi \\ Email: amirklby@yahoo.co.id \\ Muhammad Endy Fadlullah \\ Institut Agama Islam Ibrahimy Genteng Banyuwangi \\ Email: mefadlullah@yahoo.com
}

\begin{abstract}
This paper aims to explain that the phenomenon of syariah tourism in Santen Island Banyuwangi District was not always directly proportional to the ideal concept proposed by the government of Banyuwangi district. This research is a descriptive research whichtaken from qualitative data in the form of field observation, interview, and documentation as the material of analysis, so writer can find important findings. First, the big concept that is carried by the government of Banyuwangi district has not been able to be realized properly such as tourism management that has not shown syariah, lack of good understanding of the concept of syariah tourism by managers, facilities are not adequate, human resources are still low, the values of syariah aspired has not materialized, and there is no exact difference between syariah tours with conventional tourism or more precisely "syariah tour of conventional tourism". Secondly most of the visiting tourists are not satisfied and feel disappointed with the implementation of syariah tourism because they met less criteria of syariah that they expected.
\end{abstract}

Keywords: Phenomenon, Halal Tourism, Santen Island.

\section{Pendahuluan}

Sejauh ini studi tentang wisata syariah pantai dipandang sebagai sesuatu yang menarik dan seksi, karena wisata yang selama ini identik dengan rekreasi dan suka-suka dibungkus dan dilabeli dengan baju agama atau syariah sebagai brand market, dimana syariah itu sendiri syarat dengan aturan-aturan yang bersiat mengikat bagi para pemeluknya. Dewasa ini, konsep syariah seringkali digunakan oleh dari berbagai kalangan sebagai pemenuhan tujuan-tujuan strategis baik dalam bidang politik, budaya, agama, sosial, ekonomi dan tidak terkecuali dalam bidang pariwisata. Penggunaan kata syariah menjadi berfungsi sebagaimana agama itu berfungsi karena pada setiap struktur dalam sistem 
sosial, menunjukkan fungsional terhadap yang lain, sebaliknya kalau tidak fungsional maka struktur itu tidak akan ada atau hilang dengan sendirinya ${ }^{1}$. Wisata syariah sebagai sebuah konsep adalah bagian dari sebuah ide atau gagasan baru yang muncul karena melihat sebuah peluang pasar global dan ide atau gagasan itu sendiri masuk didalam salah satu unsur kebudayaan ${ }^{2}$.

Pembacaan peluang tentang potensi wisata itu tidak terlepas dari trend syari'ah itu sendiri yang kian hari semakin meningkat dan semakin menjadi gaya hidup bagi masyarakat Islam. Peningkatan dan gaya hidup ini ditandai dengan semakin banyaknya simbol-simbol dan labelisasi Islam yang digunakan oleh berbagai kalangan. Dalam hal ini, bagi kalangan tertentu ditangkap sebagai peluang pasar yang dapat dijual tak terkecuali dalam hal ini adalah pariwisata yang diberi label syariah.

Cara pandang terhadap agama terlihat sudah mulai bergeser dan berorientasi pada pemenuhan pasar. Menurut Abdullah bahwa agama dalam hal ini bukan merupakan sumber nilai dalam pembentukan gaya hidup, namun demikian lebih sebagai instrumen bagi gaya hidup itu sendiri. Kegiatan keagamaan tidak lagi dipandang sebagai laku spiritual (sakral) semata, tetapi telah pula menjadi produk yang di konsumsi dalam rangka pemenuhan pasar. Dengan demikian agama, seperti barang-barang seni, budaya telah diambil alih oleh pasar untuk dikelola sedemikian rupa sehingga ke-Islaman pun telah didefinisikan oleh pasar dengan menciptakan kategori-kategori dan assesoris. ${ }^{3}$

Dengan meningkatnya permintaan pasar akan adanya wisata, maka komodifikasi agama tak bisa dihindarkan karena para wisatawan juga ingin merasakan pengalaman berwisata dengan situasi baru. Biasanya dalam berbagai tempat kebudayaan lokal dianggap sebagai contoh utama yang sangat rentan terjadinya komodifikasi. Seperti, ritual, festival, pakaian adat dan kesenian rakyat tradisional menjadi bagian dari komoditas pariwisata, sebagaimana mereka diproduksi atau dipentaskan dengan semata-mata untuk menjadi konsumsi pariwisata yang dapat dilihat dan dinikmati.

Di Indonesia, trend syariah mendapatkan perhatian tersendiri bagi kementerian pariwisata. Sebagai negara dengan penduduk mayoritas muslim (85, $2 \%$ populasi penduduk Indonesia) Indonesia berpotensi untuk dapat mengembangkan wisata syariah atau Halal Tourism. Dari hasil kajiannya pemerintah telah menetapkan beberapa propinsi di Indonesia sebagai destinasi wisata syariah. Provinsi yang disiapkan sebagai destinasi Wisata syariah oleh pemerintah Indonesia meliputi Propinsi Nusa Tenggara Barat (NTB), Nangroe Aceh Darussalam, Sumatera Barat, Riau, Lampung, Banten, DKI Jakarta, Jawa

\footnotetext{
${ }^{1}$ Damsar, Pengantar Sosiologi Pendidikan,. (Jakarta: Kencana 2012), 19

${ }^{2}$ Koentjacaraningrat,. Pengantar ilmu antropologi. (Jakarta; Rineka Cipta 2015), 151.

${ }^{3}$ Irwan Abdullah, Konstruksi dan Reproduksi Kebudayaan. (Yogyakarta: Pustaka Pelajar 2009), 113.
} 
Barat, Jawa Tengah, Yogyakarta, Jawa Timur, Sulawesi Selatan, dan Bali. Namun dari ke-13 provinsi tersebut yang dinyatakan siap yaitu Jakarta, Jawa Barat, NTB, Yogyakarta, dan Jawa Timur. ${ }^{4}$ Kesiapan tersebut berdasarkan pada kesiapan sumber daya manusia (SDM), budaya masyarakatnya, produk wisata daerah, serta akomodasi wisatanya. Menurut Taufik Nur Hidayat Kasubdit Korporasi Direktorat MICE dan Minat Khusus Kementerian Pariwisata dan Ekonomi Kreatif, Kesiapan setiap provinsi dalam mengembangkan wisata syariah didukung oleh beberapa fasilitas yaitu hotel, restoran bersertifikat halal, biro perjalanan dan spa. ${ }^{5}$ Tidak ketinggalan Banyuwangi sebagai suatu daerah yang memiliki keberhasilan dalam mengelola pariwisata ikut andil untuk mengembangkan pariwisata yang berbasis syariah.

Untuk mengukur apakah wisata syariah itu dapat dikategorikan sebagai wisata yang Menurut Chukaew standar pengukuran pariwisata syariah dari segi administrasi dan pengelolaannya memiliki delapan faktor yakni: 1) pelayanan kepada wisatawan harus sesuai dengan prinsip-prinsip Islam secara keseluruhan, 2) staf dan pemandu harus memiliki disiplin dan menghormati prinsip-prinsip Islam, 3) semua kegiatan diatur agar tidak bertentangan dengan prinsip-prinsip Islam, 4) sarana prasarana bangunan harus sesuai dengan prinsip-prinsip Islam, 5) restoran harus berstandar internasional pelayanan halal, 6) layanan transportasi harus memiliki keamanan sistem proteksi, 7) terdapat tempattempat yang disediakan untuk para wisatawan muslim melakukan kegiatankegiatan keagamaan dan, 8) ketika bepergian ke tempat-tempat yang tidak bertentangan dengan prinsip hukum Islam 6 .

Dengan melihat standar-standar yang telah dikemukakan diatas mampukah Banyuwangi mengelola wisata syariah secara optimal. Karena wisata syariah yang dikembangkan di Banyuwangi ini bertempat di sebuah pantai yang tepatnya di pantai Pulau Santen dimana pantai itu sendiri memiliki karakteristik diantaranya: a) pantai yang secara umum dipandang sebagai tempat lepas pandang yang sangat sulit untuk diberi sekat, pantai bukan hanya sebuah tempat rekreasi tetapi bisa melakukan aktivitas berenang, merupakan tempat orang berenang (membuka pakaian/kerudung), b) perempuan yang selalu terikat dengan laki-laki terutama bagi yang sudah berkeluarga, c) berwisata adalah sebuah kegiatan yang terkait dengan suka-suka, kenyamanan, keindahan, kesenangan, dan kebersamaan, d) kesiapan pengelola terkait dengan

\footnotetext{
${ }^{4}$ Kementria n Ekonomidan Pariwisata Republik Indonesia.Undang-undang No 10 Tabun 2009. Jakarta:Kemenparekraf RI 2013.

${ }^{5}$ Sindonews.com/read/994208/162/13-provinsi-siap-jadi-tujuan-wisata-syariah1430102126/

${ }^{6}$ Chookaew, S., chanin, O., Charatarawat, J., Sriprasert, P., \& Nimpaya, S. (2015). Increasing Halal Tourism Potential at Andaman Gulf in. Journal of Economics, Business and Management, III (7), 277-279.
} 
sumberdaya manusianya (SDM) dalam mengelola wisata syariah, dan e) kesiapan penduduk dalam menerima konsep wisata Pantai Syariah.

Hal inilah yang mengusik peneliti untuk meneliti lebih lanjut tentang wisata syariah di Banyuwangi ini dengan tujuan untuk mengetahui pelaksanaan dan pandangan masyarakat terhadap wisata syariah di Pulau Santen Kabupaten Banyuwangi?. hasil penelitian ini diharapkan dapat memberikan manfaat baik dari secara akademik maupun secara nyata hasilnya dapat dijadikan bahan evaluasi untuk menjadikan wisata syariah menjadi lebih baik.

Penelitian ini merupakan penelitian kualitatif-antropologis yang dilakukan untuk mengetahui fenomena wisata syariah yang terjadi di Pulau Santen Banyuwangi, sehingga menghantarkan kepada sebuah kondisi riil pelaksanaan wisata syariah. Dalam penelitian antropologi ini, peneliti akan melakukan kajian pustaka sebelum ke lapangan. Kajian pustaka ini meliputi pemetaan masalah, perencanaan observasi, pemetaan calon informan, dan kajian penelitian-penelitian sebelumnya. Tujuan dari kajian pustaka ini untuk membantu merumuskan alur penelitian lapangan agar penelitian bisa berjalan efektif dan efisien. Setelah itu penelitiakan melakukan penelitian lapangan. Dalam penelitian lapangan ini, peneliti mengguna kan metode observasi terlibat (participantobservation) untuk mengumpulkan data baik yang tersirat maupun tersurat. Metode observasi terlibat dimaksudkan untuk menggali informasi mendalam yang mungkin tidak dapat ditangkap melalui wawancara dan data statistik sehingga originalitas makna dari sebuah peristiwa dapat ditemukan. Dalam observasi terlibat ini peneliti akan tinggal dilokasi penelitian selama dilapangan dan berbaur dengan informan. Selama tinggal di lapangan, peneliti akan mencatat gambaran umum lokasi penelitian mulai dari menginventarisir data statistik yang tersedia, memotret keseharian wisata syariah, dan termasuk menginventarisir isu-isu lokal. Dengan demikian hasil penelitian menjadi integral. Untuk memperdalam temuan-temuan awal, peneliti akan melakukan klarifikasi melalui wawancara mendalam (in-depth interview) pada informan yang representatif di lapangan, sehingga orisinalitas data tetap terjaga. Terakhir data yang telah dihimpunakan dianalisis secara etnografis dalam bentuk narasi tentang pelaksanaan wisata syariah Pulau Santen.

Selanjutnya analisis data lapangan tentang wisata syariah ini dihubungkan tentang bagaimana pandangan para pengunjung wisata terhadap wisata syariah itu sendiri serta dampak yang ditimbulkan dari keberadaan wisata syariah. Tujuan dari analisis ini adalah untuk menemukan kemungkinankemungkinan kebijakan baru yang bisa dihasilkan terkait pengelolaan ke pariwisataan.

Data primer penelitian ini adalah data kualitatif yang diperoleh dari observasi terlibat (participant observation) dan wawancara mendalam (in-depth interview) pada informan yakni pengelola wisata syariah, penduduk setempat 
dan pengunjung ditambah dengan seseorang yang dipandang perlu yang ditentukan saat dilapangan untuk dimintai keterangan untuk memperkuat data terkait dengan wisata syariah. Sedangkan data sekunder diperoleh dari kajian pustaka penelitian sebelumnya, buku-buku eksiklopedia, suratkabar, maupun informasi online yang dapat dipertanggungjawabkan.

\section{Sekelumit Tentang Pulau Santen}

Pulau Santen adalah nama sebuah pantai yang tepatnya berada di ujung timur Kelurahan Karangrejo Kecamatan Kecamatan Banyuwangi Kabupaten Banyuwangi yang terletak di sebelah selatan Stasiun lama Banyuwangi. Kelurahan Karangrejo sendiri terbagi menjadi empat lingkungan 1) lingkungan Kaliasin, 2) lingkungan Karanganom 3) lingkungan Karanganyar dan 4) lingkungan Pakem. Batas-batas wilayah Karangrejo adalah sebelah utara Kelurahan Kepatihan, sebelah selatan Kelurahan Kertosari, sebelah barat Kelurahan Tukang Kayu dan sebelah timur adalah laut selat Bali.

Nama lama pulau "Pakem", atau lengkapnya "Tanjung Pakem" ini telah tergantikan dengan sebutan Pulau Santen menjadi lebih terkenal dan polpuler di masyarakat Banyuwangi. Menurut Kholik (55) Pantai Tanjung Pakem dulu sering digunakan oleh para prajurit Bugis dan Bali sebagai pelabuhan alternatif untuk masuk ke bumi Blambangan, sehingga keberadaan pantai ini memiliki fungsi yang sangat penting. Ibukota pemerintahan Blambangan yang dulu berada di Ulupampang (sekarang Muncar) pasca perang puputan bayu dipindahkan ke tempat Banyuwangi kota pada tahun 1774. Kemudian VOC/Belanda membangun sebuah benteng di Tanjung Pakem dengan tujuan untuk mengawasi pergerakan kapal-kapal yang melintas di Selat Bali. Pembangunan benteng ini dilakukan pada bulan Agustus 1774, di bawah pengawasan seorang tukang kayu dari Surabaya yang bernama Baas d'Exter. Benteng tersebut dibangun dengan menggunakan kayu jati dengan melibatkan sebanyak 200 orang tenaga dipekerjakan. Dalam penguasaannya benteng Tanjung Pakem ini silih berganti, Belanda pergi digantikan Jepang, Jepang pergi digantikan oleh Indonesia yang kepemilikan tanahnya dimiliki oleh TNI hingga sekarang.

Pelabuhan Boom yang berada di sebelah utara Tanjung Pakem ini menjadi Satu rangkaian dengan benteng Tanjung Pakem dan di sinilah pusat aktifitas perdagangan dilakukan yang dulunya pusat aktifitas perdagangan ini berada di pelabuhan Ulupampang. Pengiriman hasil-hasil perkebunan, beras, rempah-rempah dan kayu, dikirim lewat pelabuhan ini. Bahkan pelabuhan ini dulu juga digunakan untuk penyeberangan ke Pulau Bali. Akan tetapi pada permulaan abad 20, laut mengalami sedimentasi (pendangkalan) menyebabkan aktivitas di pelabuhan ini mulai ditinggalkan karena kapal-kapal besar sulit untuk menyandar di pantai ini. Karena tempat ini tidak dapat digunakan lagi maka 
fungsi penyeberangan akhirnya dipindahkan dari pelabuhan Tanjung Pakem ke pelabuhan Ketapang, sementara fungsi perdagangan dipindahkan ke Pelabuhan Tanjung Wangi.

Kini, Pulau Santen di diami oleh orang-orang Madura yang mayoritas pekerjaannya sebagai nelayan yang datang dari pulau Madura jauh sebelum kemerdekaan mereka tinggal dan menetap disini. Pada tahun 65-an masyarakat yang mendiami Tanjung Pakem ini mulai menanam pohon santen (Kibatalia arborea) di daerah ini dengan harapan getahnya digunakan sebagai obat mata apabila mata merah atau sakit (biasanya terjadi karena terlalu lama terkena air laut, atau kelelahan), getah kayu santen diteteskan ke mata, dan tak lama kemudian mata akan kembali putih jernih dan segar seperti semula. Sementara itu daun pohon santen ini dimanfaatkan sebagai pakan ternak kambing. Karena banyak ditumbuhi pohon santen, dimana pohon santen ini bisa kita temui di pantai, di area rumah-rumah warga, sampai di area savana, maka masyarakat Banyuwangi mengenal pulau ini dengan nama Pulau Santen.

Berdasarkan keterangan dari warga yang ada di Pulau Santen, sepanjang area perairan laut Pulau Santen di bagian timur banyak terdapat terumbu karang. Terumbu karang ini menjadi habitat dan tempat tinggal bagi ikan-ikan dan berbagai biota laut lainnya. Saat ini terumbu karang tinggal kenangan. Terumbu karang di sekitar Pulau Santen kini sebagian besar telah mengalami kerusakan. Dulu masyarakat setempat maupun nelayan dari daerah lain banyak melakukan perburuan ikan-ikan hias dengan menggunakan bom ikan. Sebagian terumbu karang hidup yang tersisa masih bisa dijumpai di area pantai sekitar savana Pulau Santen namun dalam kondisi yang rusak. Penanaman kembali terumbu karang perlu menjadi sebuah program yang dilakukan di Pulau Santen, agar ekosistem pesisir Pulau Santen bisa kembali lestari.

Berdasarkan penuturan Bapak Kholik (55 tahun) yang merupakan seorang anggota TNI, Pulau Santen ini terbagi dalam tiga wilayah. Wilayah paling utara adalah kawasan milik Pelindo, wilayah tengah adalah kawasan milik TNI AD, dan wilayah paling selatan adalah kawasan milik Pemkab Banyuwangi. Masyarakat yang tinggal di wilayah Pulau Santen berada dibagian tengah yaitu di tanah milik TNI AD. Wilayah selatan Pulau Santen terdapat padang savana seluas kurang lebih tujuh hektar. Banyak orang menganggap savana ini tidak kalah indahnya dengan savana yang ada di Taman Nasional Baluran.

Pulau Santen ini merupakan kawasan yang masih memerlukan perhatian dari pemerintah daerah. Menurut warga, sejak dahulu Pulau Santen ini kurang diperhatikan oleh pemerintah kabupaten Banyuwangi. Pulau Santen berjarak kurang lebih $2 \mathrm{~km}$ dari pusat kota Banyuwangi, meskipun demikian dekat akan tetapi kurang begitu banyak program-program yang dibuat untuk mengatasi berbagai permasalahan yang ada di pulau ini. Hal ini dimungkinkan karena akses jalan menuju ke Pulau Santen kurang baik. Warga Pulau Santen jika ingin 
menuju ke daratan harus menggunakan perahu, sehingga tidak heran jika penduduk Pulau Santen jarang mengenyam pendidikan sampai tingkat tinggi kebanyakan hanya bersekolah sampai SD.

Pada masa Bupati Samsul Hadi (tahun 2000-2005) dibangunlah jembatan permanen yang menghubungkan Pulau Santen dengan daratan desa Karangrejo. Di masa ini juga Syamsul Hadi melakukan program pengadaan air bersih (air tawar) dengan jalan pemasangan pipa-pipa air yang ditempatkan di bawah konstruksi jembatan. Air bersih ini kemudian ditampung dalam tandon air untuk kemudian bisa dimanfaatkan oleh warga. Pengadaan air (tawar) bersih ini menjadi solusi cukup penting bagi kebutuhan dasar warga Pulau Santen. Meskipun debit airnya tidak terlalu besar, akan tetapi sudah sangat membantu karena dulunya warga mendapatkan air tawar harus dengan cara mengambil air ke daratan seberang dengan tong atau jirigen dan memikulnya kemudian dinaikkan ke perahu. Bagi warga yang mempunyai istri dan anak biasanya dalam sehari bisa dua kali mengambil air. Sepanjang masa pemerintahan beberapa bupati yang menjabat di Banyuwangi, program pembangunan jembatan dan pengadaan air bersih menjadi satu-satunya perhatian pemerintah yang langsung bisa dirasakan manfaat kongkritnya bagi warga. Jembatan yang telah dibangun masa bupati Ir. H. Syamsul Hadi ini diperbarui lagi oleh bupati Abdullah Azwar Anas pada awal tahun 2017 karena program bupati menjadikan Pulau Santen ini menjadi tempat wisata Pantai Syariah.

Karena tanah di Pulau Santen ini adalah bukan tanah hak milik perorangan yakni tanah milik TNI, oleh karena itu dalam membuat rumah penduduk dibangun dengan sistem semi permanen dan penduduk juga tidak dikenai biaya administrasi sewa tempat oleh TNI. Seluruhnya rumah-rumah penduduk Pulau Santen ini memiliki rumah dengan bangunan yang sederhana yakni beratapkan genteng, pilar dari kayu, berdinding tripleks (kayu lapis), berlantaikan tanah dan sebagian lagi berlataikan plester. Para penduduk Pulau Santen tidak mau membangun bangunan bagus, karena menyadari tanah yang ditempatinya adalah bukan hak miliknya.

Saat ini masalah terbesar di Pulau Santen adalah sampah. Pulau yang sebenarnya memiliki pemandangan alam yang sangat eksotis ini "ternodai" oleh keberadaan sampah yang berserakan di mana-mana baik di sungai, pantai dan juga di daratan. Sebagai perkampungan yang terletak di muara sungai dan di tepi laut sampah berdatangan dengan sendirinya ke pulau ini terbawa aliran air sungai, dibawa ombak, dan juga sampah yang dihasilkan oleh masyarakat pulau Santen sendiri. Walaupun Pulau Santen berada di Kelurahan Karangrejo, yang masih masuk dalam wilayah kecamatan Banyuwangi kota, namun petugas kebersihan belum masuk ke pulau ini. Belum ada program penanganan sampah dari pemerintah daerah. Saat ini sampah yang ada di pulau Santen belum bisa "dikeluarkan" dari pulau. Rata-rata warga mengubur sampahnya atau 
membakarnya. Beberapa komunitas yang peduli terhadap lingkungan hidup sesekali melakukan program edukasi tentang sampah, pemanfaatan sampah untuk kerajinan, pembuatan ecobrick (pemanfaatan sampah plastik dan sampah botol plastik), dll. Namun kesemuanya hanyalah inisiatif-inisiatif dari komunitas-komunitas tersebut, belum ada sentuhan maupun sinergi dari pemerintah daerah. Oleh karena itu, Pulau Santen oleh banyak kalangan menyebutnya sebagai Pantai Kumuh. Baru setelah Bupati Abdullah Azwar Anas menjadikan sebagai wisata Pantai Syariah, terdapat petugas-petugas khusus yang membersihkan sampah dengan cara menguburnya didalam pasir pantai.

Walaupun begitu sebetulnya Pulau Santen menawarkan pemandangan yang sangat indah. Pohon-pohon santen yang ada di pinggir pantai memiliki bentuk yang unik, ekosistem mangrove yang cantik, padang savana yang mempesona, itu semua adalah potensi yang sangat kaya dan mengagumkan. Wisatawan juga dapat melihat terbitnya matahari dari tempat ini sehingga Banyuwangi mendapat sebutan sunrise of java. Nelayan di Pulau Santen memiliki aktifitas yang khas seperti kegiatan jaring tarik, yaitu cara tradisional menangkap ikan secara berkelompok dengan memasang jaring panjang dari pantai ke laut menggunakan perahu kemudian jaring ditarik secara bersama-sama oleh beberapa orang dari bibir pantai. Ada lagi aktifitas masyarakat mencari kerang remis di pantai, kegiatan mencari kerang kijing di muara sungai, sampai pada pengolahan ikan ataupun kerang menjadi aneka kuliner laut yang lezat. Aktifitas kehidupan keseharian masyarakat pesisir Pulau Santen ini merupakan pemandangan yang sangat indah dan menarik bahkan sangat eksotis. Itulah kesejatian alam Pulau Santen dan kehidupan masyarakat nelayan yang tinggal di dalamnya yang membedakan dengan pantai-patai yang lain.

\section{Impian Wisata Syariah Pulau Santen}

Setiap kejadian penting pasti memiliki latar belakang cerita baik disengaja maupun tidak disengaja oleh pelakunya. Jika kelompok-kelompok individu yang memiliki latar belakang kehidupan berbeda saling berinteraksi secara langsung dan intensif, maka akan menimbulkan sebuah perubahan besar pada pola budaya salah satu atau seluruh kebudayaan yang bersangkutan. Menurut Selo Sumardjan perubahan sosial adalah perubahan-perubahan pada lembaga-lembaga masyarakat yang mempengaruhi sistem sosialnya, seperti nilainilai sosial, sikap, dan pola tingkah laku antar kelompok dalam suatu masyarakat. ${ }^{7}$ Sumarjan (1981:448-449) juga mengatakan bahwa perubahan sosial dapat dikelompokkan menjadi dua yakni perubahan yang disengaja dan perubahan yang tidak disengaja (intended and unintended change). Perubahan yang disengaja adalah perubahan yang telah diketahui dan direncanakan sebelumnya

\footnotetext{
${ }^{7}$ Selo Soemardjan, Perubahan Sosial di Yogyakarta. Jakarta: Komunitas Bambu 1981), 447
} 
oleh para anggota masyarakat yang berperan sebagai pelopor perubahan sedangkan perubahan yang tidak disengaja adalah perubahan yang terjadi tanpa diketahui atau direncakan sebelumnya oleh seorang anggota masyarakat. ${ }^{8}$ Dalam hal ini, wisata syariah dilihat dari awal mula kejadiannya adalah termasuk perubahan yang tidak disengaja, akan tetapi jika dilihat dari unsur pelaksanaannya adalah perubahan yang disengaja karena pemerintah Kabupaten Banyuwangi mempunyai tujuan dan program untuk mengubah keadaan Pulau Santen.Adapun ketidaksengajaan itu terlihat sebagaimana kisah Sulastri (35) sebagaimana diceritakan Pak Slamet (45) ketua RW Pulau Santen.

"Awal mula Pulau Santen dijadikan Pantai Syariah oleb Bupati Banyuwangi Abdullah Azwar Anas adalab begini, saya memiliki warga bernama Sulastri sedang terkena penyakit kanker payudara. Kata Atmi (51), suami Sulastri bahwa istrinya divonis dokter menderita kanker payudara stadium empat pada awal tabun 2016 dan disarankan menjalani kemotrapi selama enam kali sebelum dioperasi. "Saat itu, kondisinya sehat masih bisa berjalan". Kemoterapi ia jalani di Rumah Sakit Patrang Jember sampai empat kali. Ketika berada di rumah tiba-tiba Sulastri kejang dan kemudian lumpub total. Sulastri sempat dirawat di rumah sakit kemudian meminta pulang dan menginginkan tinggal di bagian dapur rumabnya karena lebih dingin dan nyaman ketika buang air besar dan buang air kecil, kata Sulastri. Saat pulang dari rumah sakit setelah kontrol, Tri mengaku ada gerakan di dalam perut dan ternyata diketahui kondisinya hamil 8 bulan dan akan melabirkan. Tri kemudian dievakuasi dengan becak motor lalu dipindabkan ke mobil pickup dan dibawa ke rumah sakit dan melahirkan anak laki-laki yang diberinama Muhammad Alfatib Yandra pada tanggal 12 Januari 2017. Saat melabirkan, Sulastri dalam kondisi lumpuh. Semuanya kaget karena tidak ada yang menyangka kalau Sulastri hamil dan melabirkan".

Berita tentang Sulastri ini dengan cepat terdengar dan menyebar di masyarakat tak luput Bupati Abdullah Azwar Anas bersama rombongan beberapa kepala Dinas Kabupaten Banyuwangi datang ke Pulau Santen untuk menjenguk Sulastri. Bersamaan dengan itu pula wartawan dari berbagai media massa dan elektronik juga hadir, sehingga ikut mempercepat penyebaran berita.

Ketidaksengajaan ini memberikan inspirasi baru dan ditangkap sebagai peluang pariwisata yang dapat dikembangkan menjadi destinasi baru. Mungkin, memang karena Bupati Banyuwangi adalah salah satu Bupati yang pandai dalam membaca peluang. Ketika berkunjung ke Pulau Santen dan melihat potensi alam yang eksotis, Bupati Banyuwangi tertarik untuk mengembangkan Pulau Santen ini menjadi tempat pariwisata. "Pulau Santen ini akan saya jadikan Pantai Bidadari” Kata Bupati Anas kepada Pak Slamet.

\footnotetext{
${ }^{8}$ Selo Soemardjan, Perubahan Sosial di Yogyakarta,....448-449
} 
Menurut Soniawan petugas Dinas Kebudayaan dan Pariwisata (DISBUDPAR) Kabupaten Banyuwangi, bahwa salah satu program Bupati Banyuwangi dalam mengembangkan pariwisata adalah dengan menciptakan atau membuka destinasi wisata baru setiap tahunnya, walaupun dalam hal ini tidak ditarget harus berapa jumlah destinasi yang baru. Sejalan dengan itu, Bupati Banyuwangi membentuk tim gabungan yang terdiri dari unsur Pemerintah, TNI dan Tokoh masyarakat Pulau Santen untuk mendiskusikan secara inten mengenai konsep yang tepat untuk mengelola pariwisata Pulau Santen. Diskusi secara inten itu dilakukan di balai RW Pulau santen yang tepat berada di depan rumah Pak Slamet.

Rencana Bupati Banyuwangi yang ingin menjadikan tempat wisata baru di Pulau Santen ini mulai menghembus di masyarakat setelah Bupati Banyuwangi melakukan kunjungan ke Pulau Santen. Dalam kunjungannya bersama beberapa pejabat Banyuwangi ini, Bupati mengumumkan pada media bahwa Pemerintah Kabupaten Banyuwangi berencana melakukan pengembangan destinasi wisata di Pulau Santen. Bupati juga telah mengumumkan perencanaan pengembangan wisata Pulau Santen dalam aktifitas launching Banyuwangi Festival 2017 pada hari Jumat, 3 Februari 2017. Dalam kegiatan launching 72 event Banyuwangi Festival 2017 ini bupati menjelaskan tentang rencana konsep wisata khusus perempuan yang akan dikembangkan di wilayah pantai yang berada di area savana Pulau Santen. Dalam penjelasan Bupati Banyuwangi ke berbagai media, dipaparkan bahwa di pantai area savana Pulau Santen ini nantinya akan dijadikan pantai bidadari dan dibangun "club beach for woman", yang akan dilengkapi kolam renang, bahkan resort peristirahatan. Bupati juga akan menggandeng investor untuk pengembangan wisata ini. Selain itu, direncanakan akan dibangun jembatan yang akan langsung menembus ke Pulau Santen di wilayah bagian selatan pulau ini. Hal ini dimaksudkan untuk mempermudah akses bagi wisatawan untuk bisa menuju Pulau Santen.

Bupati Banyuwangi merancang penataan Pantai Syariah Pulau Santen dengan sangat bagus. Jalan jembatan yang menuju ke Pulau Santen akan dibuat dengan desain yang menarik dengan bahan-bahan kayu ulin (Eusideroxylon zwageri). Sisi jembatan sebelah selatannya akan dibangun dan dipoles sedemikian menarik panorama hutan mangrove didesain berbentuk hati. Mangrove yang menghadap ke arah jembatan itu juga akan dibuat tulisan "I LOVE BWI. Sehingga Wisatawan bisa mengelilingi dan menikmati mangrove lewat jembatan sepanjang 100 meter.

Selanjutnya didalam Pulau tepatnya dimuara pantai sebelah utara akan dibangun plengsengan dan tepat diatas plengsengan tersebut berdiri gazebo kayu guna menyesuaikan kondisi alam sekitar. Sebelah kiri jembatan dipercantik dengan payung kain lebar yang membentang di antara pepohonan santen. 
Dibawah payung lebar tersebut akan disediakan kursi sofa angin yang akan memanjakan wisatawan menikmati indahnya Selat Bali.

Sementara itu, di bagian selatan akan dibangun Puskesmas Pembantu (Pustu) yang akan memberikan layanan kesehatan kepada masyarakat dan wisatawan. Ada fasilitas umum berupa mushola dan toilet. Selatan musola akan dibangun stan penjualan kerajinan sejumlah hasil industri kecil menengah (UKM, seperti hasil kerajinan dan makanan olahan) yang dibuat oleh warga Pulau Santen.

Rupanya pemerintah Kabupaten Banyuwangi ingin menyulap kampung Pulau Santen (PUSAN) ini yang awalnya kumoh, terbelakang, SDM rendah, kurang religius ini menjadi sebuah tempat wisata yang eksotik sekaligus religius. Konsep wisata syariah ini disambut baik oleh berbagai kalangan baik pihak pemerintah kabupaten, TNI sebagai pemilik lahan tokoh masyarakat terlebih adalah penduduk Pulau Santen karena dapat meningkatkan ekonomi warga, walapun penduduk Pulau Santen sendiri kurang memahami dengan baik apa maksudnya pemerintah kabupaten menjadikan wisata syariah ini, seperti yang diungkapkan Pak Slamet.

"Sebenarnya penduduk sini tidak paham dengan konsep syariah, saya sendiri pernah protes ke Pak. Pujo Dinas Perikanan, lo kenapa daerah kami kok jadi Pantai Syariah? dari dulu namanya kan Kampung Pusan (Pulau Santen)..kami dan warga penduduk sini tidak paham dengan bahasa-bahasa elit maklum disini SDMnya rendah rata-rata lulusan SD, tapi tidak apalah kami tetep senang karena yang penting bagi kami adalah warga kami bertambah sejabtera mendapatkan penghasilan dari adanya Pantai Syariah"

Kaitannya dengan rencana pemerintah Kabupaten Banyuwangi menjadikan wisata Pantai Syariah ini terlihat bahwa penduduk Pulau Santen sering gagap dan tidak paham dalam memahami program-program pemerintah terutama dengan maksud syariah itu sendiri. Hal ini dapat dimaklumi karena memang latar belakang pendidikan penduduk Pulau Santen ini tergolong rendah, yang terjadi adalah penduduk ini mengekor saja apa yang telah diprogramkan oleh pemerintah kabupaten.

Pulau Santen oleh pemerintah Kabupaten Banyuwangi akan ditata dan akan dikembangkan menjadi destinasi wisata unggulan yang membidik segmen pariwisata syari'ah (syaria tourism). Dalam penataan wisata syariah Pulau Santen terdapat tiga konsep besar yaitu pertama destinasi wisata berkonsep Syariah. konsep ini diambil mempunyai tujuan ; 1) Diferensiasi Banyuwangi terhadap daerah lain, 2) untuk menggaet pasar family tourism (wisatawan keluarga) yang jumlah belanjanya lebih besar lima kali lipat jika dibanding wisatawan individu, 3) membidik pasar kelas menengah muslim yang semakin hari terus tumbuh. Konsep yang diusung tidak hanya komersial, tapi juga mengutamakan 
pemberdayaan warga dimana warga ikut terlibat aktif dalam pengelolaan wisata syariah yang memberikan kualitas soaial-ekonominya semakin meningkat. Disisi selatannya bakal disulap menjadi "beach club for women". Penataan kawasan ini diharapkan bisa menjadi model pengembangan wisata sekaligus penguatan sosial-ekonomi warga.

Kedua optimalisasi modal sosial dalam pembangunan. Dalam penataan pantai syariah Pulau Santen ini dilakukan dengan cara keroyokan (bersama-sama) yakni melibatkan berbagai elemen masyarakat seperti masyarakat setempat yang menjadi subyek pengembangan dan penataan Pulau Santen untuk menjadi destinasi baru, tokoh agama dan tokoh masyarakat sebagai pendamping masyarakat, TNI sebagai pemilik lahan juga ikut aktif dalam program-program penataan, dinas kesehatan bertugas untuk meningkatkan layanan kesehatan dengan menyiapkan Puskesmas Pembantu, Dinas Pendidikan berperan meningkatkan kualitas SDM lewat pendidikan formal dan nonformal, Dinas Pekerjaan Umum (PU) bertugas menata infrastruktur (jalan, jembatan, dan sejenisnya), Dinas Pengairan bertugas membangun tangkis untuk menjaga kebersihan muara sungai dan air bersih, Dinas Sosial bertugas memberi bantuan dan fasilitas untuk masyarakat usia produktif, Dinas UKM bertugas memberi pemberdayaan UMKM dan penumbuhan wirausahawan baru dalam rangka menyambut destinasi baru, Dinas Perumahan dan Pemukiman bertugas menata kawasan kumuh dan rintisan homestay oleh warga, Dinas Pertanian bertugas mengembangkan urban farming oleh warga, Dinas Perikanan bertugas membedayakan nelayan dan kelompok usaha bersama warga, Dinas Pemuda dan Olahraga mengembangkan olahraga pantai, dan Dinas Pariwisata bertugas menguatkan konsep wisata dan promosinya.

Ketiga pemberdayaan sosial-ekonomi masyarakat adalah menjadi tujuan utama dalam pengembangan wisata syariah sehingga perekonomian masyarakat akan meningkat yang akan mengangkat status sosial masyarakat.

Optimalisasi modal sosial dalam pembangunan dan menata Pulau Santen dengan sistem keroyokan pada awalnya sudah mulai terlihat seperti bagaimana antusias dari berbagai pihak. Akan tetapi secara berangsur dari berbagai pihak mulai terlihat lesu dan menarik diri dalam keterlibatan mengelola wisata syariah Pulau Santen ini seperti diungkapkan oleh Bapak Lurah Karangrejo

Dulu saya dan sebagian pegawai kelurahan setiap hari berada di Pulau Santen ikut mengelola wisata dan bahkan dalam pelayanan kepada masyarakat, saya layani di Pulau Santen ini agar masyarakat bisa melihat langsung wisata syariah yang secara otomatis wisata menjadi ramai pengunjung dan masyarakat bisa menyebarkan informasi wisata ini..akan tetapi lama-kelamaan saya menjadi males... 
Bapak Lurah Karangrejo sendiri tidak memberikan alasan secara detil, kenapa pihak kelurahan menjadi males untuk mengelola wisata syariah Pulau Santen itu, akan tetapi dapat ditangkap bahwa pihak kelurahan merasa kurang puas dengan pelaksanaan wisata syariah.

Secara terpisah pihak TNI yang dalam hal ini yang juga terlibat dalam pengelolaan wisata tidak bisa memberikan informasi mengenai sistem pengelolaan dan program keberlanjutan wisata syariah ini dikarenakan informan kunci yang mulai awal ikut merancang dan terlibat dalam mengelola wisata syariah sedang dalam kondisi sakit strokedankembali ke rumah asalnya yaitu Jember. Kondisi ini mengakibatkan terhalangnya komunikasi (miscomunication) antara pihak kelurahan dengan pihak TNI.

\section{Pantai Syariah Antara Harapan Dan Kenyataan}

Waktu itu, jarum jam menunjukkan pukul 9.30 saya sampai di depan pintu masuk wisata Pantai Syariah Pulau Santen. Sebelum masuk lokasi wisata terdapat tempat parkir para wisatawan yang membawa kendaraan baik roda empat maupun roda dua. Di tempat parkir terdapat dua orang yang selalu siap mengatur kendaraan-kendaraan para pengunjung dengan berpakaian tanpa seragam. Satu diantara mereka, sebut saja samsul (19) berambut pendek, dibawah bibirnya terdapat jarum yang sengaja ditancapkan, di telinganya sebelah kiri berlubang sebesar jari telunjuk dan di lengan atas bergambar tato seorang wanita. Disamping menjadi juru parkir, laki-laki ini juga melayani pembelian tiket masuk ke Pantai Syariah Pulau Santen. Besaran uang parkir kendaraan adalah Rp. 2.000 baik itu kendaraan sepeda motor maupun mobil serta membeli tiket masuk ke lokasi wisata perkepala sebesar Rp.3.000 dan pengunjung mendapatkan bonus satu gelas "Teh Rio".

Ketika melewati jembatan menuju Pulau Santen. Sekitar jarak kurang lebih 100 meter lurus dari arah jembatan terlihat sebuah baner berukuran $2 \times 1$ meter terdapat tulisan "selamat datang" "syariah beach" "PUSAN (Pulau Santen) dibawahnya terdapat dua gambar. Gambar sebelah kanan (sebelah selatan) seorang laki-laki dan petunjuk arah bertuliskan "ikhwan (pria)" dan gambar sebelah kiri (utara) adalah gambar perempuan dan petunjuk arah bertuliskan "ukhti (wanita)". Di sebelah kiri gambar terdapat pagar jeruji dari besi yang memisahkan lokasi pria dan wanita. Maksud dari tulisan "ikhwan (pria) disini menurut petugas Satpol PP adalah bukan tempat khusus laki-laki, akan tetapi bermakna umum yakni siapa saja dibolehkan masuk baik laki-laki maupun perempuan. Sementara itu "ukhti (wanita) adalah lokasi yang hanya khusus perempuan saja yang boleh masuk, laki-laki tidak diperbolehkan masuk walaupun itu keluarganya.

Pada rencana awal, penempatan lokasi wanita adalah bertempat di savana atau yang disebut sebagai pantai bidadari dan dibangun "club beach for 
woman" yang jarak dari lokasi wanita yang sudah dilaksanakan kurang lebih 200 meter, akan tetapi ketika wisata syariah ini diresmikan tidak sesuai dengan yang direncanakan pada awalnya yakni berada di pantai sebelah utara. Memang jika melihat lokasi Padang Savana yang direncanakan itu lokasinya terpisah dari perkampungan, sehingga sangat strategis dan memungkinkan untuk dijadikan pantai bidadari. Alasan penempatan lokasi wanita yang ada sekarang ini menunut petugas adalah hanya bersifat sementara, pada akhirnya penempatan lokasi wanita nanti akan dipindah di padang savana.

Dari rencana yang telah diprogramkan oleh pemerintah Kabupaten Banyuwangi sampai saat ini (Desember 2017) fasilitas-fasilitas yang sudah terwujud adalah payung-payung, kursi sofa angin, mushola, tempat wudlu, toilet, sementara fasilitas-fasilitas yang lain yang diprogramkan sebagian besar belum terealisasikan.Fasilitas mushola yang sudah ada memiliki luas $5 \times 3$ meter terbuat dari kayu berdinding anyaman bambu. Didalamnya tersedia peralatan sholat (mukenah) bagi wanita. Di samping selatan musola terdapat menara terbuat dari besi dengan tinggi 7 meter, sayangnya menara itu tidak ada pengerasnya, di sebelah selatan mushola juga disediakan tempat wudhu yang terbuat dari tandon air PDAM dan di sebelah utara mussola terdapat toilet. Selain itu, pengelola juga menyediakan payung-payung dan dibawahnya tersedia tempat duduk santai yang terbuat dari busa. Tempat duduk itu disewakan Rp. 10.000/jamnya, dan jika dalam keadaan sepi tempat duduk itu dibiarkan saja oleh petugas (tidak ditarik biaya).

Dari fasilitas-fasilitias yang telah ada yang belum memadai adalah tembat ibadah yang berupa mushalla kecil, tempat wudlu hanya berada di tempat wanita, tidak ada petugas pemimpin ibadah/imam/muadzin, tidak ada pengeras suara untuk mengumandangkan Adzan sehingga para wisatawan dapat terpanggil untuk menunaikan ibadah). Dari fasilitas-fasilitas yang sudah tersedia diatas yang sudah terlihat bagus dan indah adalah payung-payung yang dibawahnya terdapat kursi sofa yang dapat memanjakan para wisatawan untuk menikmati indahnya laut.

Peraturan yang mendapatkan prioritas penting bagi petugas adalah memisahkan pengunjung laki-laki dan pengunjung perempuan. Jika terjadi pelanggaran (kaum laki-laki masuk di lokasi perempuan) maka para petugas Satpol PP dengan tegas menegurnya. Dalam pelaksanaan wisata syariah terdapat aturan tata terbib yang ditulis dan dipasang dibawah pohon yang harus dipatuhi oleh para wisatawan. Tata tertib itu adalah lain:1)Kawasan sebelah kiri khusus untuk wanita, 2)Pengunjung wajib mengenakan pakaian yang sopan, 3)Para pengunjung wajib membawa kantong plastik untuk tempat sampahnya sendiri dan ketika pulang membuangnya di tempat yang sudah disediakan, 4)Pada saat mendengar suara adzan harus menghentikan segala jenis aktifitas (bagi yang muslim untuk melaksanakan sholat di mushola, 5)Dilarang membawa senjata 
tajam atau minuman keras, 6)Dilarang merusak fasilitas dan tanaman yang ada, dan 7)Dilarang membuat kebisingan.

Dari peraturan-peraturan yang telah dibuat ternyata tidak berjalan secara efektif terbukti banyak pengunjung laki-laki yang masuk begitu saja ketempat lokasi perempuan. Kenyataan ini membuat petugas Satpol PP sibuk memberikan peringatan atau pelarangan masuk ke lokasi wanita bagi kaum pria. Kondisi yang semacam ini sering terjadi cekcok dan adu mulud antara petugas dan para pengunjung laki-laki yang pada umumnya adalah keluarga dari si perempuan itu. Hal ini seperti diungkapkan oleh salah satu pengunjung

"Lo mas ini kan istri saya. Saya disini ingin berekreasi bersama keluarga, kalau saya tidak boleh dengan istri saya apa gunanya saya berekreasi...."

Rasa kecewa itu muncul dikarenakan pengunjung merasa keinginan bersantai dengan keluarga tidak terpenuhi. Protes itu juga pernah dilakukan oleh wisata perempuan tentang keberadaan Satpol PP laki-laki ini yang berada di lokasi wanita.

“...Mas sampean kan juga laki-laki kenapa berada di lokasi wanita? Harusnya sampean juga tidak boleh berada di lokasi ini, berarti sampean juga melanggar..."

Dalam melaksanakan tugasnya Satpol PP sering mengalami kebingunan dikarenakan antara perintah ideal yang harus dijalankan dengan kenyataan yang harus dihadapi sangatlah berbeda. Satu sisi ingin tegas di sisi yang lain petugas sendiri ragu dengan tindakannya dan menyadari untuk memisahkan antara lakilaki dan perempuan terlebih itu keluarga sangatlah tidak mengenakkan. Petuagas Satpol PP itu menuturkan.

"Sebenarnya saya sendiri juga tidak enak.. untuk menegur kalau itu keluarganya, tapi harus bagaimana ini adalah tugas....Sebenarnya pemandangan pantai ini bagus..seandainya wisata ini tidak diberi sekat kemungkinan akan ramai...."

Secara terpisah, ungkapan agak mengejutkan ternyata datang dari pihak Dinas Kebudayaan dan Pariwisata (selanjutnya saya sebut Disbudpar) sebagai pengelola wisata syariah di Pulau Santen, beliau yang tidak mau disebutkan namanya mengungkapkan bahwa

"Sebenarnya saya sendiri kurang paham dengan konsep wisata syariah, yang saya tahu wisata syariah itu ya laki-laki dan perempuan dibuat terpisah itupun saya tahunya dari Bupati.."

Lebih lanjut beliau mengatakan bahwa 
"Saya sendiri sebenarnya kurang sepakat dengan Bupati tentang konsep wisata syariah Pulau Santen, dengan memisahkan antara laki-laki dan perempuan itu sangat tidak efektif dalam pelaksanaannya dan program semacam itu sulit untuk diterapkan. Sebenarnya dalam hati saya tidak yakin dengan konsep wisata syariah itu, tapi harus bagaimana kalau sudah Bupati yang memerintahkan ya kita harus laksanakan mas...”

Dalam penuturannya dengan peneliti, pihak Disbudpar beliau malah mengharap kepada peneliti untuk memberi masukan-masukan untuk pelaksanaan wisata Syariah yang ada di Pulau Santen agar menjadi lebih baik lagi, karena ia sendiri merasa kurang begitu paham dengan konsep wisata syariah. Ketidak pahaman tentang konsep syariah bagi pengelola ini dikarenakan kurang adanya diskusi yang melibatkan para ahli di bidang agama, sehingga tidak ada masukan yang dari pihak yang lebih memahami tentang konsep syariah. pelaksanaan wisata syariah yang terlihat dan terkesan terburu-buru dan kurang dipersiapkan sarana pendukunya baik pendukung sumberdaya manusianya maupun pendukung fasilitas-fasilitas yang ada. Kondisi yang semacam ini menimbulkan dampak yang sangat buruk terhadap berbagai pihak baik pihak pengelola yang dianggap kurang profesional, tidak paham dengan konsep syariah yang sesungguhnya, pihak pengunjung yang merasa kecewa dengan pelaksanaan wisata syariah, terlebih bagi para pedagang yang sepi pembeli karena memang pengunjungnya yang relatif sepi. Warung makanan dan minuman yang terdapat di tempat lokasi sebanyak 12 warung. Seiring berjalannya waktu karena kondisi wisata sepi yang tampak hanya 1 warung saja yang masih membuka warungnya. Kondisi ini dikeluhkan oleh para pemilik warung yang salah satunya diungkapkan pemilik warung.

“.....itu mas seandainya tidak ada pembagiannya pasti ramai...soalnya yang datang ke sini kebanyakan keluarga yang di inginkan adalah kebersamaan kalau laki-laki tidak boleh masuk tidak nyaman sekali. Ini berpengaruh dengan warung kami..”

Secara lebih detil ketidaksiapan ini tercermin dalam potret wisata asing. Waktu itu, kondisi pantai tidak terlalu ramai pengujung sekitar 20an orang. Datanglah 4 orang wisatawan dari mancanegara 3 orang adalah laki-laki dan 1 perempuan. Mungkin memang adat barat dengan adat timur memanglah berbeda. Keempat wisatawan asing itu dengan santainya menuju pantai masuk kawasan wanita dimana orang laki-laki tidak boleh masuk di area itu. Keempat wisata asing itu dengan cepat mencopot baju dan yang masih melekat di tubuhnya adalah celana dalamnya dan langsung berlari menuju laut dan mandi.

Sontak saja penjaga itu bingung bagaimana harus mengigatkan, pengunjung-pengunjungpun yang berasal dari lokal juga merespon kejadian itu 
dan banyak yang protes ke petugas. Akhirnya datanglah seorang laki-laki bertubuh kekar berkulit hitam berambut gondrong, berpakaian you can see dan di lengannya terdapat tato. Dia adalah warga Pulau Santen yang juga ikut membantu menjaga Pantai Syariah. Laki-laki itu juga tidak bisa berbahasa inggris, akhirnya ia keluar dengan membawa sepeda motor dan tidak lama kemudian ia membonceng seseorang, ia Rangga badannya tinggi kira-kira 170 meter berkulit hitam, berambut pendek dan di lengannya juga terdapat tato. Rangga berlari ke bibir pantai dan meneriaki 4 orang wisata asing yang lagi asik mandi, setelah itu secara bersama wisata asing itu mendekati Rangga. Setelah diberitahu oleh Rangga, keempat wisata asing itu dengan membawa tas rangsel dan pakaiannya menuju ke tempat lokasi umum selatannya lokasi wanita.

Potret kejadian diatas menunjukkan tentang ketidakpahaman dan ketidaksiapan serta kurangnya sosialisasi pengelola kepada wisatawan asing pengelola dalam mengelola wisata syariah. Tidak paham atau gagal dalam memahami syariah yang ditunjukkan dengan pemindahan wisata asing ketempat lokasi pria (umum) yang masih dalam kondisi hanya memakai celana dalam saja dan yang hanya melewati pagar besi. Tidak siap sumberdaya manusianya yang ditunjukkan tidak bisanya petugas berbahasa inggris, petugas dari unsur warga yang masih mengenakan simbol-simbol tato, anting-anting bagi laki-laki, berambut gondrong, pemilik warung yang tidak berkerudung, tidak ada suara adzan dan kurangnya simbol-simbol keislaman yang dapat dinikmati oleh wisatawan, kurangnya fasilitas-fasilitas yang menunjang wisata syariah, sehingga setelah pulang dari wisata syariah, wisatawan mendapatkan hikmah-hikmah yang dapat dipetiknya.

\section{Interpretasi Wisata Syariah di Mata Wisatawan}

Dalam memahami sebuah konsep, manusia memiliki interpretasiinterpretasi makna yang berbeda-beda dan terkadang jauh dari konsep yang telah dirumuskan para ahli dalam literatur-iteratur ilmiah. Begitu juga tentang konsep wisata syariah sebagaimana diprogramkan oleh Bupati Banyuwangi ini ternyata mempunyai banyak interpretasi dari masyarakat. Menurut Blumer manusia bertindak terhadap sesuatu berdasarkan makna-makna yang ada pada sesuatu itu. Makna di peroleh dari hasil interaksisosial yang dilakukan dengan orang lain, dan makna-makna itu disempurnakan pada saat proses interaksisosial yang sedang berlangsung. Dalam hal ini seseorang tidak hanya bertindak terhadap tindakan yang lain, tetapi juga menafsirkan dan mendefinisikan setiap tindakan orang lain. ${ }^{9}$ Penafsiran masyarakat dalam memahami wisata syariah dapat ditemukan dalam fikiran dan tingkahlaku mereka ketika berwisata syariah di Pulau Santen. Sebagai susunan makna, kebudayaan boleh dikatakan bersifat

${ }^{9}$ Herbert Blumer, The Society for Social Research" dalam J. Thomas (ed). The Chicago School: Urban Life. Vol. 11 No.4 p.421-439. 
ideasional, tetapi ia tidak terdapat di dalam benak seseorang seperti yang di percaya oleh kaum kognitif atau etnosaintis. Kebudayaan tidak berada di dalam benak atau pikiran seseorang lantaran ia besifat publik, sebagaimana halnya makna itu sendiri pun bersifat publik. ${ }^{10}$

Dalam berwisata seseorang mempunyai tujuan-tujuan yang antara lain ingin berlibur, rekreasi, bersenang-senang bersama keluarga, saudara dan temanteman. Pilihan tempat tujuan untuk berwisata biasanya dilatarbelakangi oleh dua hal yakni pertama bahwa tempat tujuan sudah diketahui keindahannya dan kedua tujuan wisata belum pernah diketahuinya, akan tetapi seseorang tertarik untuk datang karena penasaran. Pengunjung yang datang ke wisata Pantai Syariah ini pada umumnya mereka belum pernah datang ke tempat ini dan di ilhami penasaran tentang Pantai Syariah itu seperti apa. Rasa penasaran ini muncul karena wisata syariah ini merupakan destinasi baru yang dengan kebaruan itu pastilah terdapat sesuatu yang berbeda dari yang lain.

Sudah menjadi rahasia umum dikalangan masyarakat Banyuwangi bahwa Bupati Abdullah Azwar Anas ini adalah bupati yang cerdas dan pandai dalam berinovasi terutama dalam bidang pariwisata. Terbukti beberapa tempat pariwisata yang ada di Banyuwangi baik destinasi wisata baru maupun destinasi wisata yang sudah ada yang dulunya sepi sekarang ramai dikunjungi wisatawan baik domestik maupun mancanegara. Sehingga ketika ada sebuah wisata baru, masyarakat berduyun-duyun untuk datang ke tempat itu seperti halnya di Pantai Syariah Pulau Santen.

Bayangan yang muncul bagi para wisatawan sebelum datang ke tempat wisata Pantai Syariah ini sebagian besar memiliki kesamaan yakni sebuah wisata yang didalamnya terdapat simbol-simbol keislaman seperti yang perempuan harus berkerudung, terdapat tulisan-tulisan yang bernuansa religius, terdapat warung-warung halal, kesenian-kesenian religi dan lain-lain. Sebagian kecil lagi mereka tidak memiliki bayangan apapun, hanya penasaran saja. Akan tetapi apa yang dibayangkan tidak selalu sama dengan kenyataan. Kesan yang muncul setelah masyarakat datang ke Pantai Syariah ini secara umum adalah mereka kurang puas dan sebagian kecewa berwisata di Pantai Syariah ini. Alasan-alasan ketidakpuasan ini antara lain adalah tidak sesuai dengan yang dibayangkan sebelum datang ke Pantai Syariah ini, Pantai Syariah ini biasa-biasa saja tidak ada bedanya dengan wisata-wisata yang lain dan tidak sesuai dengan syariah. Hal ini seperti yang dituturkan salah satu pengunjung Balya ketika sedang berwisata di tempat ini.

"Apanya yang syariah mas? Masak seperti ini syariah? saya kira wisata ini tidak ada bedanya dengan wisata yang lain yang bukan syariah, yang membedakan hanya pembatas saja"

${ }^{10}$ Clifford Geertz, Interpretation of Cultures. (New York: Basic Books 1973),... 10 
Ketidakpuasan dan kekecewaan ini berimplikasi kepada meraka yang tidak ingin kembali lagi mengunjungi wisata Pantai Syariah ini. Terbukti pada saat awal dibukanya Pantai Syariah pengunjungnya sangat ramai bisa mencapai ratusan orang dan secara berangsur-angsur pengunjung mengalami pengurangan yang sangat drastis hingga penelitian ini dilakukan terlihat sepi pengunjung lebih-lebih pada hari senin sampai jum'at hampir tidak ada pengunjungnya, namun pada hari sabtu sore dan minggu pengunjung paling banyak 25- 50 orang.

Akan tetapi sampai pada bulan Desember 20017 bertepatan dengan liburan panjang sekolah yakni mulai tanggal 17 sampai 1-31 Desember $2017+$ 1 Januari 2018 kondisi wisata mulai berubah, para pengunjung ramai dan puncaknya pada 1 Januari 2018 pengunjung sangat ramai. Para petugas yang berasal dari para pemuda warga Pulau Santen sibuk mengatur parkir, persewaan kursi sofa angin, yang menjadi aneh adalah tidak terlihatnya sama sekali petugas yang berseragam Satpol PP. Peraturan-peraturan seperti pemisahan antara pengunjung pria dan pengunjung wanita yang awalnya masih diberlakukan, kini tidak diberlakukan lagi pengunjung pria dengan bebas masuk ke kawasan wanita sehingga tidak bisa dibedakan lagi mana kawasan wanita dan mana kawasan pria (umum) dan sampai disinilah konsep wisata syariah yang telah direncanakan oleh pemerintah Kabupaten Banyuwangi dengan bagus menjadi rontok dengan sendirinya.

Dari paparan data diatas terlihat bahwa pelaksanaan wisata syariah di Pulau Santen tidak bisa berjalan dengan efektif dan nilai-nilai syariah yang dicitacitakan belum terwujud wisata syariah oleh para petugas dipahami hanya tentang pemisahan antara pengunjung pria dengan pengunjung wanita saja. Pemahaman pengelola wisata terhadap wisata syariah terlihat kurang didasari atas keilmuan yang mendalam sehingga pelaksanaan wisata syariah tidak terlihat adanya perbedaan antara wisata syariah dengan wisata konvensional dan diakhir penelitian ini dilakukan (awal Januari 2018) wisata syariah murni terlihat sebagai wisata konvensional atau lebih tepatnya "wisata syariah berasa wisata konvensional".

Pengetahuan masyarakat dalam memahami konsep wisata syariah itu sendiri ternyata sangat beragam yakni ada yang memahami secara dalam dan ada juga yang memahaminya secara sederhana. Pemahaman secara mendalam biasanya dimiliki oleh orang-orang yang memiliki latar belakang keluarga dan pendidikan yang berbasis agama sementara pemahaman sederhana biasanya dimiliki oleh orang-orang yang memiliki latar belakang keluarga dan pendidikan umum. Pengunjung yang memahami wisata syariah yang mendalam biasanya lebih idealis dan lebih menekankan kepada aturan-aturan agama sebagai acuannya, sementara yang memahami secara sederhana mereka lebih terlihat 
cuek dan tidak bisa menjelaskan aturan-aturan syariah yang seharusnya dilakukan oleh pengunjung, yang penting mereka senang bisa menikmati.

Dari hasil wawancara dengan pengunjung menunjukkan bahwa mereka berharap kepada pemerintah dan pengelola wisata Pantai Syariah ini memperbaiki manajemen wisata syariah, sehingga sesuai dengan apa yang diharapkan. para pengunjung menyayangkan dengan manajemen yang terlihat kurang bagus dan asal-asalan. Hal ini tidak sesuai dengan tujuan wisata syariah itu sendiri yaitu meningkatkan spiritualitas dan menumbuhkan kesadaran bergama para pengunjung khususnya wisatawan muslim setelah pulang dari tempat wisata.

\section{Kesimpulan}

Fenomena wisata syariah yang dikembangkan pemerintah Kabupaten Banyuwangi memiliki tiga konsep besar yaitu; pertama destinasi wisata berkonsep Syariah. konsep ini diambil mempunyai tujuan ; 1) Diferensiasi Banyuwangi terhadap daerah lain, 2) untuk menggaet pasar family tourism (wisatawan keluarga) yang jumlah belanjanya lebih besar lima kali lipat jika dibanding wisatawan individu, 3) membidik pasar kelas menengah muslim yang semakin hari terus tumbuh. Kedua optimalisasi modal sosial dalam pembangunan yang dilakukan dengan cara keroyokan (bersama-sama) yakni melibatkan berbagai elemen masyarakat seperti masyarakat setempat, tokoh agama dan tokoh masyarakat, TNI, dinas kesehatan, Dinas Pendidikan, Dinas Pekerjaan Umum (PU), Dinas Pengairan, Dinas Sosial, Dinas UKM, Dinas Perumahan dan Pemukiman, Dinas Pertanian, Dinas Perikanan, Dinas Pemuda dan Olahraga, dan Dinas Pariwisata. Ketiga pemberdayaan sosial-ekonomi masyarakat adalah menjadi tujuan utama dalam pengembangan wisata syariah sehingga perekonomian masyarakat akan meningkat yang akan mengangkat status sosial masyarakat.

Konsep besar yang telah di rencanakan dalam pelaksanaannya ternyata belum bisa diwujudkan dengan baik seperti pengelolaan wisata yang belum menunjukkan syariah, kurang dipahaminya dengan baik konsep wisata syariah oleh pengelola, fasilitas-fasilitas yang belum memadai, sumberdaya manusianya yang masih rendah, terlihat bahwa pelaksanaan wisata syariah di Pulau Santen tidak bisa berjalan dengan efektif dan nilai-nilai syariah yang dicita-citakan belum terwujud serta tidak terlihat adanya perbedaan antara wisata syariah dengan wisata konvensional atau lebih tepatnya "wisata syariah berasa wisata konvensional". Kondisi yang demikian berdampak kepada sebagian besar wisata yang berkunjung ke Pantai Syariah Pulau Santen kecewa. Fenomena wisata syariah ini menunjukkan bahwa harapannya adalah sangat idealis akan tetapi pelaksanaannya belum maksimal.

\section{Daftar Pustaka}


Abdullah, Irwan 2009. Konstruksi dan Reproduksi Kebudayaan. Yogyakarta: Pustaka Pelajar.

Alim, Haidar Tsany dkk. (tantap tahun). Analisis Potensi Pariwisata Syariah Dengan Mengoptimalkan Industri Kreatif Di Jawa Tengah Dan Yogyakarta. Semarang: Jurusan Akuntansi Fakultas Ekonomika Dan Bisnis Universitas Diponegoro.

Chookaew, S., chanin, O., Charatarawat, J., Sriprasert, P., \& Nimpaya, S. (2015). Increasing Halal Tourism Potential at Andaman Gulf in. Journal of Economics, Business and Management, III (7), 277-279.

Blumer, Herbert,1983, The Societyfor Social Research"dalamJ.Thomas(ed).The Chicago School:Urban Life. Vol. 11 No.4 p.421-439.

Damsar, 2012. Pengantar Sosiologi Pendidikan. Jakarta: Kencana.

Embree,L.1994."ReflectionontheCulturalDisciplines"dalamPhenomenologyof The CulturalDisciplines.ManoDanielandLesterEmbree(ed.).Boston:

KluwerAcademicPublishers.

Geertz, Clifford,1965,Mojokuto: DinamikaSosialSebuah KotadiJawa.Jakarta: PT. Grafitipers.

------------, 1973, Interpretation of Cultures. New York: Basic Books

Hekman,S.1980."Phenomenology, Ordinary Language,and The Methodology Of The Social Sciences". The Western Political Quarterly, Vol. 33, No.3 (Sep.,1980):341-356.

Jones, P. 2009. Pengantar Teori-Teori Sosial dari Teori Fungsionalisme binggaPostModernisme.Jakarta:YayasanOborIndonesia.

Pratiwi, Ade Ela. Analisis Pasar Wisata di Kota Yogyakarta. Jurnal Media Wisata Volume 14. No. 1 Mei:2016

Kementrian Ekonomidan Pariwisata Republik Indonesia. 2013.UndangundangNo 10 Tabun 2009. Jakarta:KemenparekrafRI

Kompas. 2014. 9 Destinasi wisata syariah di Indonesia. (http://travel.kompas.com/read/2014/01/07/1717322/Inilah.9.Destin asi.Wisata.Syariah.di.Indonesia. Diakses tanggal 12 Juli 2017)

Koentjacaraningrat, 2015. Pengantar ilmu antropologi. Jakarta; Rineka Cipta

Psathas,G.2005."IdealTypein WeberandSchutz"dalamExplorationsofTheLifeWorld Continuing Dialogues with Alfred Schut:Martin Endress, George Psathasand HisashiNasu(ed.).Dordrecht:Springer.

Rosyidi, I. 2005. Intensionalitas dalam Fenomenologi Edmund Husserl (18591938).Tesis Pascasarjana Ilmu Filsafat.Yogyakarta:Universitas Gadjah Mada.

Salim, Agus. 2005. Teori dan Paradigma Penelitian Sosial. Yogyakarta: TiaraWacana.

Syarifuddin, Amir, Haji. 1997. Ushul Fiqh Jilid 1. Jakarta: Logos Wacana Ilmu. 
Soemardjan, Selo,1981, Perubahan Sosia ldi Yogyakarta. Jakarta: Komunitas Bambu.

Sugiarti, Ariqa Nurwilda. 2015. Strategi Pengembangan Pariwisata Syariah Untuk Meningkatkan Kunjungan Wisatawan Muslim Domestik Dan Mancanegara Di Kota Bandung. Bandung: Universitas Pendidikan Indonesia.

Suwandono, Harjanto. 2015. Potensi Pengembangan Pariwisata Perbotelan Di Kota Semarang (Kajian Dari Perspektif Syariah). Tesis. Surakarta: Program Studi Magister Manajemen Program Pasca Sarjana Universitas Sebelas Maret Surakarta.

Sindonews.com/read/994208/162/13-provinsi-siap-jadi-tujuan-wisatasyariah-1430102126/

Tim Peneliti. 2015. Laporan Akbir Kajian Pengembangan Wisata Syariah. Asisten Diputi Penelitian dan Pengembangan Kebijakan Kepariwisataan Diputi Bidang Pengembangan Kelembagaan Kepariwisataan Kementerian Pariwisata. 